\title{
Revised Finnish classification of indoor climate 2018
}

\author{
Mervi Ahola $^{1 *}$, Jorma Säteri ${ }^{2}$ and Laura Sariola ${ }^{3}$ \\ ${ }^{1}$ Finnish Society of Indoor Air Quality and Climate, FISIAQ, Finland \\ ${ }^{2}$ Metropolia University of Applied Sciences, Helsinki, Finland \\ ${ }^{3}$ The Building Information Foundation RTS sr; Finland
}

\begin{abstract}
The Finnish Society of Indoor Air Quality and Climate (FiSIAQ) introduced a Classification of Indoor Climate, Construction Cleanliness, and Finishing Materials in 1995. The Classification of Indoor Climate has been revised to meet the new Decree on indoor air quality and ventilation, European standards and experience from users of the classification. The most significant change is that target values for concentration and the in/out ratio of fine particles have been added. Other adjustments have been made to ensure good indoor environment and energy efficiency, but with reasonable investments. The criteria for emissions from building material and furniture were also updated. The Building Information Foundation RTS sr has run the M1-labelling of building products since 1996. The voluntary approach has been proven to improve the IAQ in new buildings and to reduce emissions from building materials. The Classification of Indoor Environment 2018 is integrated part of the new RTS Environmental Classification system.
\end{abstract}

\section{Background}

Good indoor environment is one of the most important objectives of construction. Indoor climate quality is affected equally by heating, ventilation, and airconditioning equipment; construction engineering; the quality of the construction work; building materials; and the use and maintenance of the building. Good indoor environment requires taking all these elements into consideration in all stages of the design, construction, and use of the building.

Improving indoor air quality in all the sectors are in great importance in Finland. First part of The Classification of Indoor Environment (CIE) 2018 [1] include new Requirements for Technical Target Values. The other part, Guidance for design and Construction, include surface structural design, construction site design, Classification of Construction and Construction Work Cleanliness (P1), Classification of Building Materials (M1), Cleanliness Class of Air-handling components (M1) and instructions for designing mechanical systems for buildings.

The classification is intended for the setting of indoor air targets concerning usual work and occupied spaces (including office and public buildings, schools, day-care centres, dwellings). The classification is primarily used to set indoor climate targets for S1 and S2 categories for new buildings when seeking even better indoor climate than required in the regulations.

The classification is not an official code or an interpretation of one. The factors mentioned in the classification bind the contracting parties only to the extent in which they are specifically referred to in the contract documents for the construction project.
The Classification of Indoor Environment 2018 has been updated based on user experience and latest research knowledge. It also takes into account the requirements by the Ministry of Social Affairs and Health [2] and the Ministry of the Environment [3], as well as changes in European standards.

\section{Structure of the classification}

The Classification of Indoor Environment has three parts:

1. The classification of indoor climate gives target and design values for thermal conditions, odour intensity, noise levels, ventilation and indoor air pollutants.

2. Guidelines for design and construction including classification of cleanliness in construction, principles and procedures for the main stages of construction works.

3. The Emission Classification of Building Materials contains target values for odours and emissions of the materials, fixtures and furniture and recommended maximum surface area of materials based on their emissions.

The targets, requirements, and instructions of the classification shall be taken into consideration at all stages of the construction project. The developer or subscriber chooses the target values for the indoor environment in collaboration with the design team.

The classification is intended for the setting of indoor air targets concerning usual work and occupied spaces (including office and public buildings, schools, day-care centres, dwellings). The classification is primarily used to set indoor climate targets for S1 and S2 categories for new buildings when seeking even better

\footnotetext{
* Corresponding author: mervi.ahola@sisailmayhdistys.fi
} 
indoor climate than required in the regulations. It can also be applied to set goals for basic improvement projects.

The classification has three categories: categories $\mathrm{S} 1, \mathrm{~S} 2$, and S3. Category S1 is the most probable to achieve higher occupant satisfaction than in other categories. Setting clear goals for indoor environment promotes solid collaboration between the various actors and therefore reduces the risk of problems impairing health or comfort.

S1 category: Individual indoor environment

The indoor air quality of the space is very good and there are no detectable odours in the environment. There are no damages in the spaces or structures connected to indoor air which would decrease the quality of indoor air, and there are no sources of impurities. Thermal environment is comfortable, and there is no draught or overheating. The user of the space may individually control the thermal conditions. The space has a very good acoustic environment in view of its use and individually adjustable lighting supporting good lighting conditions.

S2 category: Good indoor environment

The indoor air quality of the space is good, and there are no disturbing smells in the environment. There are no damages in the spaces or structures connected to indoor air which would decrease the quality of indoor air, and there are no sources of impurities. Thermal environment is good. There is usually no draught, but overheating is possible on summer days. The space has a good acoustic and lighting environment in view of its use.

S3 category: Satisfactory indoor environment The indoor air quality and thermal conditions as well as the lighting and sound conditions meet the minimum requirements set by Land use and Building codes and the minimum standards set by the Health Protection Act $[2,3]$. Fulfilling the requirements of the Building code does not necessarily require the use of S3 target values. The S3 class values are presented here primarily to support comparison.

The target and design values for individual factors can be selected from different categories, or, if necessary, the value of a factor can be specified separately.

\section{New Criteria of the Classification of Indoor Environment}

\subsection{Thermal conditions}

Table1 presents the technical target values for thermal environment in the indoor air categories S1 and S2 that shall be used to specify the target level for indoor environment during the design phase of the construction project.
Table 1. Target values for operative temperatures in S1 and S2 categories.

\begin{tabular}{|c|c|c|}
\hline & S1 & S2 \\
\hline $\begin{array}{l}\text { Operative } \\
\text { temperature } \mathrm{t}_{\mathrm{op}}\left[{ }^{\circ} \mathrm{C}\right] \\
\mathrm{t}_{\mathrm{u}} \leq 10^{\circ} \mathrm{C} \\
10<\mathrm{t}_{\mathrm{u}} \leq 20^{\circ} \mathrm{C} \\
\mathrm{t}_{\mathrm{u}}>20^{\circ} \mathrm{C}\end{array}$ & $\begin{array}{l}21,5 \\
21,5+0,15 \mathrm{xt}_{\mathrm{u}} \\
24,5\end{array}$ & $\begin{array}{l}21,5 \\
21,5+0,2 \mathrm{xt}_{\mathrm{u}} \\
25,5\end{array}$ \\
\hline $\begin{array}{l}\text { Allowable deviation } \\
\text { range of the } \\
\text { operative } \\
\text { temperature }\left[{ }^{\circ} \mathrm{C}\right] \\
\text { deviation up: } \\
\mathrm{t}_{\mathrm{u}} \leq 0^{\circ} \mathrm{C} \\
0<\mathrm{t}_{\mathrm{u}} \leq 15^{\circ} \mathrm{C} \\
\mathrm{t}_{\mathrm{u}}>15^{\circ} \mathrm{C} \\
\text { deviation down: }^{\circ} \\
\mathrm{t}_{\mathrm{u}} \leq 0^{\circ} \mathrm{C} \\
0<\mathrm{t}_{\mathrm{u}} \leq 20^{\circ} \mathrm{C} \\
\mathrm{t}_{\mathrm{u}}>20^{\circ} \mathrm{C}\end{array}$ & $\begin{array}{l}<22.5 \\
<22.5+0.166 \mathrm{xt}_{\mathrm{u}} \\
<25 \\
>20.5 \\
>20.5+0.075 \mathrm{xt}_{\mathrm{u}} \\
>22\end{array}$ & $\begin{array}{l}<23 \\
<23+0.2 \mathrm{xt}_{\mathrm{u}} \\
<26 \\
>20.5 \\
>20.5+0.025 \mathrm{xt}_{\mathrm{u}} \\
>21\end{array}$ \\
\hline $\begin{array}{l}\text { Maximum value of } \\
\text { the operative } \\
\text { temperature }\left[{ }^{\circ} \mathrm{C}\right] \\
\mathrm{t}_{\mathrm{u}} \leq 0{ }^{\circ} \mathrm{C} \\
0<\mathrm{t}_{\mathrm{u}} \leq 20^{\circ} \mathrm{C} \\
\mathrm{t}_{\mathrm{u}}>15^{\circ} \mathrm{C}\end{array}$ & $\begin{array}{l}<23 \\
<23+0.2 \mathrm{xt}_{\mathrm{u}} \\
<27\end{array}$ & $\begin{array}{l}<23 \\
<23+0.2 \mathrm{xt}_{\mathrm{u}} \\
<27\end{array}$ \\
\hline $\begin{array}{l}\text { Minimum value of } \\
\text { operative } \\
\text { temperature }\left[{ }^{\circ} \mathrm{C}\right]\end{array}$ & $>20$ & $>20$ \\
\hline
\end{tabular}

Figures 1 and 2 present new and previous target values. Grey area is the allowable deviation range. In the previous version deviation was $\pm 0,5^{\circ} \mathrm{C}(\mathrm{S} 1)$ and $\pm 1,0^{\circ} \mathrm{C}(\mathrm{S} 2)$ of the target value. This was considered to be too strict to be achieved with reasonable costs.

Operative temperature in the occupied zone $\left[{ }^{\circ} \mathrm{C}\right]$

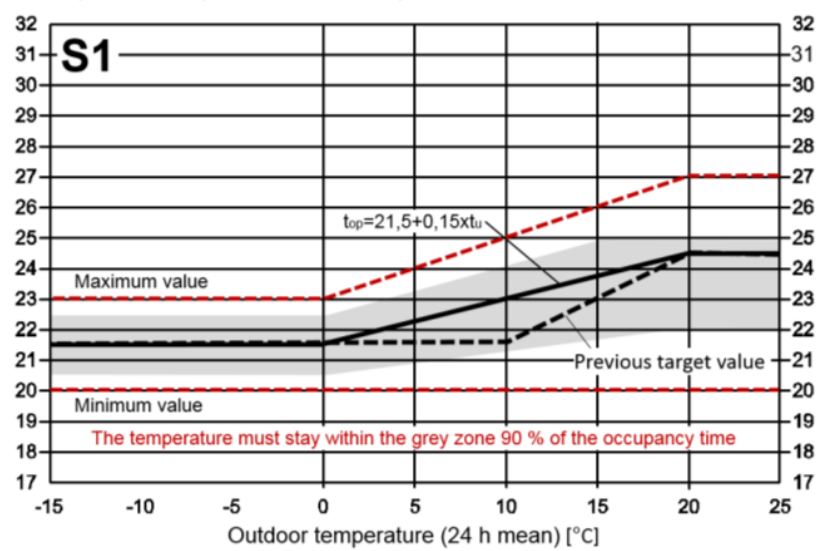

Fig. 1. Target values for operative temperature in category S1. Dotted line presents previous target values. The grey area represents the target value range (target temperature +allowable deviation range) 


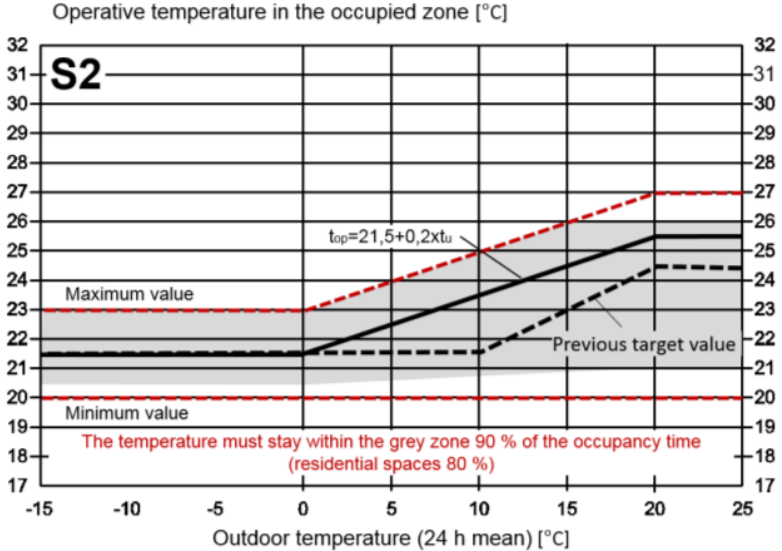

Fig. 2. Target values for operative temperature in category S2. Dotted line presents previous target values. The grey area represents the target value range (target temperature +allowable deviation range)

Temperature control is essential for the indoor environment. In the updated classes $\mathrm{S} 1$ and $\mathrm{S} 2$, the temperature must stay within $90 \%$ of the operating time in the grey area. There is an exception in the class S2 for residences where the temperature must stay $80 \%$ of the time within grey area.

Table 2. Target values for operative temperatures in S1 and S2 categories.

\begin{tabular}{|l|l|l|}
\hline & $\mathrm{S} 1$ & $\mathrm{~S} 2$ \\
\hline Draft rate (DR) [\%] $]^{* *}$ & 10 & 15 \\
\hline Air speed [m/s] & & \\
$\mathrm{t}_{\text {air }}=21^{\circ} \mathrm{C}$ & $<0.15$ & $<0.15$ \\
$\mathrm{t}_{\text {air }}=23^{\circ} \mathrm{C}$ & $<0.15$ & $<0.20$ \\
$\mathrm{t}_{\text {air }}=25^{\circ} \mathrm{C}$ & $<0.20^{*}$ & $<0.25^{*}$ \\
\hline
\end{tabular}

* Locally, higher air speeds can be accepted to increase thermal comfort when there is no mechanical cooling.

** The draft rate describes the percentage of occupants complaining of draft in accordance of temperature, average air speed and turbulence. The calculation of draft rate is presented in standard ISO 7730[4].

Changes made in the operative temperature target value have two results. First it allows temperature rise in the midterm. This will reduce investment costs. Second it will reduce energy consumption by allowing higher temperatures but also by allowing lower temperatures. By allowing lower temperatures will enable the use of night cooling.

Draught is a common complaint in mechanically cooled buildings. Special attention must be paid to air diffusion and other factors in design. Dynamic simulations are recommended to ensure comfortable thermal conditions.

\subsection{Indoor air quality}

The carbon dioxide concentration target applies to carbon dioxide from humans and the value is reported as carbon dioxide concentration add (higher than in outdoor air) in the updated version of CIE 2018. The target value was reported as carbon dioxide concentration in the CIE 2008 version. PM2.5 $[\mu \mathrm{g} / \mathrm{m} 3]$ - particulate matter is dust floating in the room air and measured according to the standard EN 12341[5]

Table 3. Target values for indoor air quality

\begin{tabular}{|c|c|c|}
\hline $\begin{array}{c}\text { Carbon dioxide concentration, } \\
\text { add * }[\mathrm{ppm}]\end{array}$ & $\mathrm{S} 1$ & $\mathrm{~S} 2$ \\
\hline Radon concentration $\left[\mathrm{Bq} / \mathrm{m}^{3}\right]$ & $<100$ & $<100$ \\
\hline $\mathrm{PM}_{2.5}\left[\mu \mathrm{g} / \mathrm{m}^{3}\right]$ & $<10$ & $<10$ \\
\hline $\mathrm{PM}_{2.5}$ indoor/outdoor & $<0,5$ & $<0,7$ \\
\hline $\begin{array}{c}\text { Stability of environment } \\
{[\% \text { of operating time] }} \\
\text { office and school spaces } \\
\text { residential spaces }\end{array}$ & $90 \%$ & $90 \%$ \\
$80 \%$ & $80 \%$ \\
\hline
\end{tabular}

*above the carbon dioxide concentration in the outdoor air

Fine particles are the biggest factor causing environmental burden of disease in Finland [6]. This is even the outdoor air on Finland is one of the cleanest in the world. Because of that, target values for $\mathrm{PM}_{2.5}$ concentration and in/out ratio are set. Efficient filtration must be designed so that targets are met.

\subsection{Acoustic environment}

The acoustic environment of the building is designed according to standard SFS 5907: Acoustics classification of spaces in buildings. In this standard, class A refers to the highest target level and class $\mathrm{C}$ to the lowest, minimum level. The acoustic class of the space is determined separately for each space. In indoor environment category S2, class $\mathrm{C}$ is the target but targets from class B can also be selected for individual spaces. In indoor environment category $\mathrm{S} 1$, class $\mathrm{B}$ is the target but targets from classes $\mathrm{A}$ and $\mathrm{C}$ can also be selected for individual spaces.

Table 4. Target levels of acoustic environment for open-plan office

\begin{tabular}{|c|c|c|c|c|}
\hline Measurement & Label & Unit & S1 & $\mathrm{S} 2$ \\
\hline $\begin{array}{l}\text { Weighted standardized } \\
\text { sound level difference to } \\
\text { office }\end{array}$ & $\mathrm{D}_{\mathrm{nT}, \mathrm{w}}$ & $\mathrm{dB}$ & $\geq 30$ & $\geq 25$ \\
\hline $\begin{array}{l}\text { Weighted standardized } \\
\text { sound level difference to } \\
\text { conference room }\end{array}$ & $\mathrm{D}_{\mathrm{nT}, \mathrm{w}}$ & $\mathrm{dB}$ & $\geq 35$ & $\geq 30$ \\
\hline $\begin{array}{l}\text { Weighted standardized } \\
\text { impact sound pressure level } \\
\text { from surrounding spaces }\end{array}$ & $\begin{array}{l}\mathrm{L}_{\mathrm{nT}, \mathrm{w}}+ \\
\mathrm{C}_{\mathrm{I}, 50-2500}\end{array}$ & $\mathrm{~dB}$ & $\leq 63$ & $\leq 63$ \\
\hline Distraction distance $^{2)}$ & $\mathrm{rD}$ & $\mathrm{m}$ & $\leq 4$ & $\leq 6$ \\
\hline Speech transmission index ${ }^{3)}$ & STI & - & $\leq 0,5$ & $\leq 0,5$ \\
\hline Reverberation time ${ }^{1)}$ & $\mathrm{T}$ & $\mathrm{S}$ & $\leq 0,4$ & $\leq 0,5$ \\
\hline $\begin{array}{l}\text { Sound pressure level from } \\
\text { building service equipment }\end{array}$ & $\mathrm{L}_{\mathrm{A}, \mathrm{eq}}$ & $\mathrm{dB}$ & 35 & 35 \\
\hline $\begin{array}{l}\text { Sound pressure level of } \\
\text { sources external to the } \\
\text { building }\end{array}$ & $\begin{array}{l}\mathrm{L}_{\mathrm{A}, \mathrm{eq}}, \\
07-22\end{array}$ & $\mathrm{~dB}$ & $\leq 40$ & $\leq 40$ \\
\hline
\end{tabular}


1) Reverberation time applies to frequencies between $250-4000$ $\mathrm{Hz}$. At frequencies between $250-4000 \mathrm{~Hz}$, a deviation of $\pm 0.1 \mathrm{~s}$ is allowed. At a frequency of $125 \mathrm{~Hz}$ a deviation of $\pm 0.3 \mathrm{~s}$ is allowed.

2) Distraction distance $\mathrm{rD}_{\mathrm{D}}$ is measured in accordance with ISO 3382-3, where the measurements compensate for the reverberation time in open-plan offices. $\mathrm{r}_{\mathrm{D}}$ is the distance beyond which the STI value of the speech transmission index falls below 0.50 . The reference values are shown in RIL 243-3-2008.

3) The speech transmission index will be measured according to the Ministry of the Environment guideline.

Open-plan offices should have a background noise level of 40-45 dB L $\mathrm{L}_{\text {Aeq, }}$, so that speech does not stand out over long distances. Easiest way to create background noise is with a separate noise masking system.

\subsection{Airtightness of the building envelope}

The airtightness of the building envelope and the structures between the indoor spaces have a significant effect on the transfer of pollution to indoors and between spaces. Good airtightness reduces energy consumption, moisture risk of the envelope and draft due to air leakage.

When aiming at a good quality indoor environment (categories $\mathrm{S} 1$ and $\mathrm{S} 2$ ), the target airtightness must be $\mathrm{q}_{50}$ $\leq 1.0 \mathrm{~m}^{3} / \mathrm{h}, \mathrm{m}^{2}$. The air leakage factor $\left(\mathrm{q}_{50}\right)$ of the building envelope at a pressure difference of $50 \mathrm{~Pa}$ is determined in standard ISO 9972:2015 [7] using measurement method B (testing the building envelope).

The realization of the airtightness target chosen by the developer shall be verified by a leak test in Indoor environment categories S1 and S2. Leakage detection and possible sealing of the leakages should be done during the leak test.

\subsection{Ventilation}

Ventilation is used for removing primarily contaminants and humidity caused by humans. The adverse effects of construction and furnishing materials must be eliminated mainly using low emission materials (e.g., class M1 in the Emission Classification of Building Materials) as well as following installation instructions of the materials. The outside air flow rates of the spaces have been adopted from standard EN 16798-3:2017 [8]. Indoor environment category S1 corresponds to the standard's category I and category S2 to its category II. In adherence to the instructions of this classification for selection of construction materials, cleanliness, and humidity management in construction work, it is possible to use the design values of a 'very low-polluting building' in buildings where smoking is prohibited.

S1 category, outdoor air flow

$=0.5 \mathrm{dm}^{3} / \mathrm{s} \cdot$ floor $-\mathrm{m}^{2}$ and additionally $10 \mathrm{dm}^{3} / \mathrm{s} \cdot$ person

S2 category, outdoor air flow

$=0.35 \mathrm{dm}^{3} / \mathrm{s} \cdot$ floor- $\mathrm{m}^{2}$ and additionally $7 \mathrm{dm}^{3} / \mathrm{s} \cdot$ person

S3 category, outdoor air flow

$=0.35 \mathrm{dm}^{3} / \mathrm{s} \cdot$ floor $-\mathrm{m}^{2}$ or at least $6 \mathrm{dm}^{3} / \mathrm{s} \cdot$ person
Table 5 presents the design values conformant to this design principle for outdoor air flows for various spaces. The control of room temperature or preparing for flexibility may require greater air flow. If there are specific sources of contaminants, the need for extra air flow must be taken into consideration on a case-by-case basis. It must be possible to adjust the air flow when the use of the space changes.

Table 5. The design values in the normal usage situation of outdoor air flow in spaces that meet the criteria for a building causing very little pollution

\begin{tabular}{|l|c|c|c|c|c|}
\hline Space & & \multicolumn{2}{|c|}{ Category S1 } & \multicolumn{2}{c|}{ Category S2 } \\
\hline & $\begin{array}{c}\text { Floor } \\
\text { surface } \\
\left(\mathrm{m}^{2} / \text { person }\right)\end{array}$ & $\begin{array}{c}\mathrm{dm}^{3} / \mathrm{s} \\
\text { per } \\
\text { person }\end{array}$ & $\begin{array}{c}\mathrm{dm}^{3} / \mathrm{s} \\
\mathrm{per} \mathrm{m}^{2}\end{array}$ & $\begin{array}{c}\mathrm{dm}^{3} / \mathrm{s} \\
\text { per } \\
\text { person }\end{array}$ & $\begin{array}{c}\mathrm{dm}^{3} / \mathrm{s} \\
\mathrm{per} \mathrm{m}^{2}\end{array}$ \\
\hline $\begin{array}{l}\text { Office space, normal } \\
\text { space efficiency }\end{array}$ & $10 \ldots 12$ & 16 & 1.5 & 11 & 1.0 \\
\hline $\begin{array}{l}\text { Office space, high } \\
\text { space-efficiency }\end{array}$ & $6 \ldots 8$ & 14 & 2.0 & 9 & 1.5 \\
\hline Conference room & 3 & 12 & 4.0 & 8 & 3.5 \\
\hline Break room, canteen & 1.5 & 11 & 5.0 & 8 & 4.0 \\
\hline Hotel room & & 10 & & 8 & \\
\hline Classroom & 2 & 11 & 5.5 & 8 & 4.0 \\
\hline Lecture room & & 10 & & 8 & \\
\hline Day-care centre & 3 & 12 & 4.0 & 8 & 3.0 \\
\hline
\end{tabular}

Outside normal occupied times, the building must have an average minimum-ventilation of $0.15 \ldots 0.2$ $\mathrm{dm}^{3} / \mathrm{s} \cdot \mathrm{m}^{2}$, so that the air changes in all rooms and that the pressure difference between the outside and the indoor air does not change because of the ventilation. Minimumventilation is used to remove the impurities originating from the building and it may be used only when there are no occupants in the space. After minimum-ventilation phase, the ventilation must be run at normal level for two hours before the users arrive at the building

The ventilation of occupied rooms and bedrooms in flats is designed according to Table 6 . The air flows of other spaces in apartments shall be designed according to FINVAC project [9] (also presented at this congress)

Table 6. Design values for outdoor air flow in residential spaces

\begin{tabular}{|l|l|c|c|c|}
\hline Usage & Unit & S1 & S2 & S3 \\
\hline Normal use $^{1)}$ & $\begin{array}{l}\mathrm{dm}^{3} / \mathrm{s}, \\
\text { person }\end{array}$ & 10 & 8 & 6 \\
\hline $\begin{array}{l}\text { Boost, apartment-specific } \\
\text { increase option }\end{array}$ & $\%$ & 30 & 30 & 30 \\
\hline $\begin{array}{l}\text { Basic ventilation outside } \\
\text { the time of use }\end{array}$ & $\mathrm{dm}^{1 / 3} / \mathrm{s}, \mathrm{m}^{2}$ & 0.2 & 0.2 & 0.15 \\
\hline
\end{tabular}

${ }^{1)}$ Air flows are measured, for example, with fixed device, a measurement device, a hot-wire anemometer, or the bag method according to the CEN-EN 12599 [10].

2) It must be possible to increase the air flows temporarily to remove the contaminants produced. It is recommended that the ventilation of the flat be boosted overall and direct the boost to washing rooms and restrooms and/or range hood.

${ }^{3)}$ Outside normal usage times, the building must have minimum ventilation with which impurities originating 
from the building are removed. This minimum ventilation outside usage time may only be used during long-term absence (more than one day), assuming, for example, that the wet spaces do not remain wet.

\subsection{The criteria for Emission Classification of Building Materials (M1)}

Various chemicals are emitted from building and interior decoration materials into room air. They may originate, for example, from the raw materials used, defects in the manufacturing process, or the ageing of the materials. Improper use of materials may also be a reason for emissions. The concentration of contaminants in the room air depends on the total emission of the materials and on ventilation. The concentration of contaminants in the room air can be diminished by decreasing the total emission or by increasing the ventilation and improving ventilation effectiveness. In aiming for a low concentration of chemicals, the total emission quantity should primarily be controlled using low-emission materials and only secondarily should the ventilation be increased.

The criteria for Emission Classification of Building Materials include EU-LCI values of single VOCs in the revised version. Other criteria deal with TVOC, formaldehyde, ammonia, CRM-substances and odour acceptability. The measurement protocol has been updated to align with the EN 16516 [11]. Upholstered office chairs is the most recent product group added to the M1-labelling (Table 7). The chairs have one emission class, M1, and the emissions are measured after 3 days.

In the emission classification of building materials, they are divided into three classes, of which M1 is the highest. Classes M1 and M2 include emitted tested building materials and uncoated furniture whose emissions fulfil the requirements of Table 6 at the age of four weeks. Class M3 materials with emissions exceeding the requirements of class M2.

Table 6. Requirements for building materials

\begin{tabular}{|l|l|l|}
\hline Properties to be examined & $\begin{array}{l}\mathbf{M} 1 \\
{\left[\mathbf{m g} / \mathbf{m}^{2} \mathbf{h}\right]}\end{array}$ & $\begin{array}{l}\mathbf{M} 2 \\
{\left[\mathbf{m g} / \mathbf{m}^{2} \mathbf{h}\right]}\end{array}$ \\
\hline $\begin{array}{l}\text { The total emission of Volatile } \\
\text { Organic Compounds (TVOC). } \\
\text { At least 70\% of the compounds } \\
\text { must be identified. }\end{array}$ & $<0,2$ & $<0,4$ \\
\hline Isolated VOC $\mu \mathrm{g} / \mathrm{m}^{2}$ & $\leq$ EU-LCI & $\leq$ EU-LCI \\
\hline $\begin{array}{l}\text { Emission of formaldehyde } \\
(\mathrm{HCOH})\end{array}$ & $<0,05$ & $<0,125$ \\
\hline Emission of ammonia $\left(\mathrm{NH}_{3}\right)$ & $<0,03$ & $<0,06$ \\
\hline $\begin{array}{l}\text { Emission of CMR compounds of } \\
\text { class 1A and 1B according to } \\
\text { classification (EC) No } \\
1272 / 2008^{1)}\end{array}$ & $<0,005$ & $<0,005$ \\
\hline Odour acceptability & $+0,0$ & $+0,0$ \\
\hline
\end{tabular}

Table 7. Requirements for upholstered office chairs in accordance with class M1

\begin{tabular}{|l|l|}
\hline Properties to be examined & $\begin{array}{l}\mathbf{M 1} \\
{\left[\mu \mathrm{g} / \mathbf{m}^{3}\right]}\end{array}$ \\
\hline $\begin{array}{l}\text { The total emission of Volatile Organic } \\
\text { Compounds (TVOC). At least } 70 \% \text { of the } \\
\text { compounds must be identified. }\end{array}$ & $\leq 20$ \\
\hline Single VOC $\mu \mathrm{g} / \mathrm{m}^{3}$ & $\leq \mathrm{EU}-\mathrm{LCI} \leq 10$ \\
\hline Emission of formaldehyde $(\mathrm{HCOH})$ & $\leq 10$ \\
\hline Emission of ammonia $\left(\mathrm{NH}_{3}\right)$ & $\leq 10$ \\
\hline $\begin{array}{l}\text { Emission of CMR compounds of class } 1 \mathrm{~A} \\
\text { and } 1 \mathrm{~B} \text { according to classification (EC) No } \\
1272 / 2008^{1)}\end{array}$ & $\leq 1$ \\
\hline Odour acceptability & $+0,0$ \\
\hline
\end{tabular}

\section{Conclusions}

With continuous update of the existing classification systems and with wide cooperation of the construction industry it is possibly to create and maintain successful methods and tools in striving for healthier and more comfortable buildings and in addition to improve construction processes and maintenance of the premises. The Classification of Indoor Environment has been used in multiple projects from the beginning.

The main changes in the 2018 edition are revised target values for indoor operative temperature, inclusion of a $\mathrm{PM}_{2,5}$ criteria, revision of some acoustical target values and revision of recommended outdoor air flows. Regarding thermal comfort, the target values of the individual indoor climate, S1, will be slightly more demanding than the targets of the S2, good indoor climate, class. The criteria for particulate matter, $\mathrm{PM}_{2,5}$, has been included due to the significant health impact of fine particles. The targets for acoustic environment in offices have been revised to reflect the importance of speech transmission. The recommended outdoor air flows follow the principles of EN 16798-3, considering the common usage of very low-emitting M1-class materials in Finland. The outdoor air flow rates have also been aligned with the recently changed building code values.

Manufacturers have developed low-emitting products during the years to meet the requirements. At the moment (February 2019) there are over 5200 M1-labelled low emitting building materials, fixture, furniture and ventilation components. These products are commonly used in residential and commercial buildings in Finland. The criteria for Emission Classification of Building Materials now include the EU-LCI value of single VOCs. Other criteria deal with TVOC, formaldehyde, ammonia, CRM-substances and odour acceptability. The measurement protocol has been updated to align with the EN 16516. Upholstered office chairs is the most recent product group added to the M1-labelling. The chairs have one emission class, M1, and the emissions are measured after 3 days. 
The purpose of the classification is to help the user, building owner, developer, and designer of the building to set the target levels for indoor environment. Based on current knowledge of health and comfort, the target levels specified in the classification describe safe indoor environment conditions, the quality of which exceeds the requirements set by authorities. The Classification of Indoor Environment 2018 (classes S1, S2) and subclassifications (P1) and (M1) are integrated part of the new Finnish environmental classification system for building processes RTS Environmental Classification launched in the spring 2017 and updated in September 2018.

\section{References}

1. Classification for Indoor Environment 2018, Finnish Society of Indoor Air Quality and Climate, FISIAQ. Espoo, Finland, The Building Information Foundation RTS sr, Helsinki, Finland

2. Decree of the Finnish Ministry of Social Affairs and Health on Health-related Conditions of Housing and Other Residential Buildings and Qualification Requirements for Third-party Experts. 545/2015

3. Decree of the Finnis Ministry of the Environment on the Indoor Climate and Ventilation of New buildings. $1009 / 2017$.

4. ISO 7730. Ergonomics of the thermal environment Analytical determination and interpretation of thermal comfort using calculation of the PMV and PPD indices and local thermal comfort criteria. 2005.

5. DIN EN 12341 Ambient air - Standard gravimetric measurement method for the determination of the $\mathrm{PM}_{10}$ or $\mathrm{PM}_{2,5}$ mass concentration of suspended particulate matter. 2014.

6. O. Hänninen, A. Asikainen, Efficient reduction of indoor exposures - Health benefits from optimizing ventilation, filtration and indoor source controls, (http://www.julkari.fi/handle/10024/110211) 2013

7. ISO 9972. Thermal performance of buildings Determination of air permeability of buildings - Fan pressurization method. 2015.

8. DIN EN 16798. Energy performance of buildings Ventilation for buildings - Part 3: For non-residential buildings - Performance requirements for ventilation and room-conditioning systems (Modules M5-1, M54). 2017.

9. FINVAC 2018. Opas ilmavaihdon mitoitukseen asuinrakennuksissa. (Guidelines for ventilation design residential buildings. Also presented in this congress)

10. CEN - EN 12599. Ventilation for buildings - Test procedures and measurement methods to hand over air conditioning and ventilation systems. 2012.

11. EN 16516. Construction products - Assessment of release of dangerous substances - Determination of emissions into indoor air. 2018. 